\title{
Host-parasite relationships: occurrence and effect of the parasitic isopod Mothocya epimerica on sand smelt Atherina boyeri in the Mesolongi and Etolikon Lagoons (W. Greece)
}

\author{
Ioannis Leonardos ${ }^{1, *}$, Jean-Paul Trilles ${ }^{2}$ \\ ${ }^{1}$ Biological Applications and Technology Department, University of Ioannina, 45110 Ioannina, Greece \\ ${ }^{2}$ Laboratoire d'Ecophysiologie des Invertébres, Université de Montpellier 2, Sciences et Techniques du Languedoc CP 092 , \\ Place E. Bataillon, 34095 Montpellier Cedex 5, France
}

\begin{abstract}
The parasite-host relationship between Mothocya epimerica, Costa 1851 (Isopoda: Flabellifera: Cymothoidae) and sand smelt Atherina boyeri (Osteichthyes: Atherinidae) fish populations were studied in the Mesolongi and Etolikon Lagoons (W. Greece). Prevalence varied during the year from $12.5 \%$ in November to $52.5 \%$ in September; overall mean prevalence was $41.9 \%$. Parasite size increased with host size. Infections did not have a significant effect on the host's body condition, such as length-weight relationship, gonadosomatic index, hepatosomatic index and relative condition factor. Histological damage to the host was observed on the gills (especially in the second and third and arches upon which the female parasite rests her abdomen). The physiological cost resulting from this infection seems to be little and probably does not constitute a serious threat for individual host survival.
\end{abstract}

KEY WORDS: Mothocya epimerica - Isopoda · Cymothoidae · Atherina boyeri · Atherinidae · Parasite $\cdot$ Host-parasite relationships

\section{INTRODUCTION}

Isopods are dorsoventrally flattened crustaceans. Parasitic isopods are among the dominant groups of crustacean ectoparasites of fish; about 450 species are parasites of marine and freshwater fish (Moller \& Anders 1986). Most are cymothoid flabelliferans, a group of isopods with a short free-living planktonic phase. Sexual dimorphism is the rule among the members of the Cymothoidae, and the life cycle is protandric. Males are of a similar size and shape to females at the aegathoid stage, which makes it difficult to separate males from immature females; however, females are relatively larger and their bodies asymmetrically proportioned in all other stages. Females brood their eggs in a marsupium under the thorax. The male phase continues through several additional moults until a second individual attaches itself to the same host. The presence of mature females inhibits further development of males in their vicinity. After that the larger of the 2 isopods is transformed into a functional female and begins to produce eggs (Sindermann 1990, Grabda 1991, Trilles 1994).

Mothocya epimerica, Costa 1851 (Isopoda: Flabellifera: Cymothoidae) parasitizes mainly the branchial cavities, as well as the buccal cavity of sand smelt fish belonging to the genus Atherina (Osteichthyes: Atherinidae) (Trilles 1968, 1994, Bruce 1986, Bello et al. 1997).

Mothocya epimerica is found in the Atlantic and in various parts of the Mediterranean Sea, including the 
Black Sea. In the Adriatic Sea this parasite has been reported in the Lesina Lagoon (Bello et al. 1997), and in several different places along the Croatian coast (Radujkovic et al. 1984, Trilles 1994). Information regarding the biology of $M$. epimerica is somewhat scarce (Trilles 1964a,b, 1991, 1994, Bello et al. 1997), and few aspects of its life history are known.

Several aspects of life history of Atherina boyeri have been recorded at various locations in the Mediterranean Sea (Kiener \& Spillman 1969, Boscolo 1970, Kohler 1976, Palmer et al. 1979, Gon \& BenTuvia 1983, Palmer \& Culley 1983, Henderson \& Bamber 1986, 1987, Bamber \& Henderson 1988, Fernandez-Delgado et al. 1988, Creech 1992, Leonardos \& Sinis 2000, Leonardos 2001).

The effects of the cymothoid infection vary according to the combination of the host-parasite status, with regard to the injurious effects on host species. These effects include: behavioral changes; tissue damage; decrease in mean weight, size and growth; and in some cases, death (Brusca 1978, 1981, Romestand \& Trilles 1979, Kabata 1984). In contrast, other studies concluded that infected fish were not significantly less healthy than non-infected ones (Brusca 1981, Landau et al. 1995, Bello et al. 1997, Colorni et al. 1997). Similarly Weinstein \& Heck (1977) suggested that host damage, if any, due to cymothoid infection is minimal.

The aim of this study is to quantify the occurrence, to evaluate the effect of infection, and to improve our knowledge of the life cycle of Mothocya epimerica on Atherina boyeri in the Mesolongi and Etolikon Lagoons (W Greece).
Mesolongi Lagoon has a mean and maximum depth of 0.5 and $2 \mathrm{~m}$, respectively. During the sampling period (April 1989 to June 1990) the salinity ranged from 9.2 to $28.0 \mathrm{psu}$, surface water temperature from 7.0 to $27.8^{\circ} \mathrm{C}$ and dissolved oxygen from 3.4 to $8.9 \mathrm{ppm}$.

Fishing was carried out at monthly intervals, during the period April 1989 to June 1990. Samples were collected from a station in the northwest of the Mesolongi Lagoon (Fig. 1) near the opening of the Etolikon Lagoon. A beach seine, mesh size $2.5 \mathrm{~mm}$, length $15 \mathrm{~m}$, height $1.5 \mathrm{~m}$ at the edges and $2 \mathrm{~m}$ in the center, terminating in a sac with a diameter of $1.5 \mathrm{~m}$ and length $3 \mathrm{~m}$, was used. Sand smelts and parasites were killed and preserved in $10 \%$ buffered formalin. During the sampling period, water temperature, salinity and dissolved oxygen were regularly measured.

Fish fork length (FL) was measured using a digital micrometer with a precision of $0.01 \mathrm{~mm}$. Total (TW) and somatic weight (NW) of the fish was measured using an electronic balance with a precision of $0.1 \mathrm{mg}$, after the removal of the intestines, hepatopancreas and gonads. The gonads and hepatopancreas of the sand smelt were weighed (to the nearest $0.1 \mathrm{mg}$ ) and the gonadosomatic $[$ GSI $=($ gonad $w e i g h t / N W) \times 100]$ and hepatosomatic [LSI $=($ liver weight $/ \mathrm{NW}) \times 100]$ indices were calculated. The relative condition factor $[\mathrm{Kn}=$ (NW/relative weight)] was also estimated. The indices and the condition factor were studied to investigate any potential influence of parasitosis to the body condition of the host.

The mouth and branchial cavities of each fish were examined under a dissecting stereomicroscope for the

\section{MATERIALS AND METHODS}

The study was conducted at the Mesolongi and Etolikon lagoonal system $\left(38^{\circ} 15^{\prime}\right.$ to $38^{\circ} 30^{\prime} \mathrm{N}$ and $21^{\circ} 05^{\prime}$ to $21^{\circ} 35^{\prime}$ E) (Fig. 1), which is among the largest in the Mediterranean, with a surface area of about $150 \mathrm{~km}^{2}$. The Etolikon Lagoon is of tectonic origin, and constitutes the northern part of the system; it has a mean depth of $12 \mathrm{~m}$ and a maximum of $33 \mathrm{~m}$. During the sampling period (April 1989 to June 1990), the salinity ranged from 10.1 to $25.0 \mathrm{psu}$, surface water temperature from 8.0 to $28.7^{\circ} \mathrm{C}$ and dissolved oxygen from 2.9 to $9.1 \mathrm{ppm}$. The Mesolongi Lagoon comprises the central and southern part of the lagoonal system and was formed through the silting action of 2 adjacent rivers: the Acheloos and Evinos. The

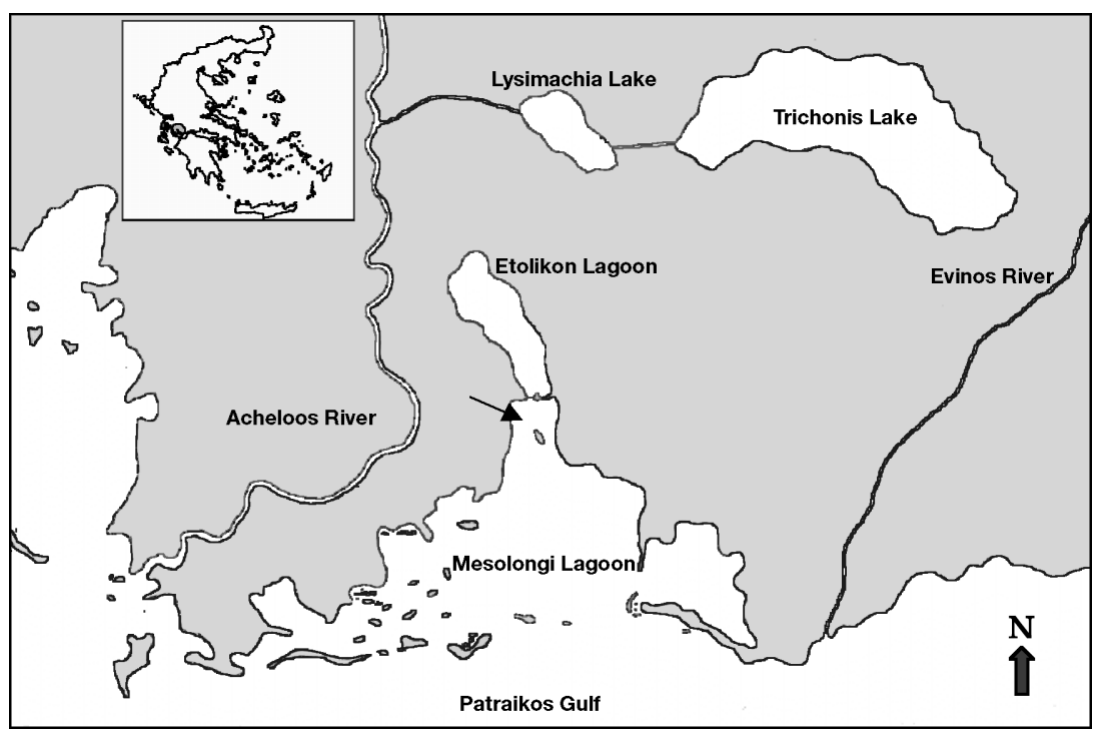

Fig. 1. Map of Mesolongi and Etolikon Lagoons. Arrow marks sampling site 
presence of parasites. The parasites on each fish were counted, their sex was determined, then they were weighed to the nearest $0.1 \mathrm{mg}$ and measured (total length, TL) to the nearest $0.1 \mathrm{~mm}$. Analysis of the parasite size-frequency distribution was performed using Hasselblad's method (Hasselblad 1966), after adaptation and modification by FiSAT (Gayanilo \& Pauly 1997).

The relationship between TL and TW of parasites was examined for males and females separately and for both sexes combined, and the slopes of the equations were compared using an analysis of covariance (ANCOVA) (Zar 1984).

The relationships between parasite and host size (weight and length) were analyzed, and it was found that the linear regression had the best fit. Sand smelt size and parasite size were log transformed before calculation of the regression.

To evaluate the effect of parasite infection on the relationship between NW and FL of the sand smelt, the parameters of the NW-FL relationship equation of specimens infected with parasites were compared with those of parasite-free specimens, using ANCOVA (Zar 1984). Moreover, the relationship between TL and TW of the parasite was calculated for each sex separately, and the slopes were compared using an ANCOVA model. Finally, the allometric coefficient ' $b$ ' describing the rate of parasite mass-increase relative to fish length was compared with that of the relationship between fish weight to fish length.

\section{RESULTS}

Mothocya epimerica was the only metazoan parasite observed in the branchial cavities of the sand smelt Atherina boyeri. Of 1112 sand smelts, 419 were found to carry 466 parasites, corresponding to an overall prevalence of $41.91 \%$. A total of 234 parasites were found in the left branchial cavity, 205 parasites in the right branchial cavity and 27 in the buccal cavity of the host (Table 1). Infected A. boyeri usually carried parasites in 1 branchial cavity; 371 (33.36\%) specimens car-

Table 1. Number of host sand smelt Atherina boyeri examined, isopod parasite Mothocya epimerica prevalence, and their location on host fish

\begin{tabular}{|c|c|c|c|c|c|c|c|c|}
\hline \multirow{3}{*}{ Host } & \multirow{3}{*}{$\mathrm{N}$} & \multirow{3}{*}{ - Host $-\overline{\% \text { infested }}$} & \multirow{2}{*}{\multicolumn{2}{|c|}{ Left branchial }} & \multicolumn{2}{|c|}{ Parasite location } & \\
\hline & & & & & Right $\mathrm{k}$ & branchial & Bucc & al cavity \\
\hline & & & Male & Female & Male & Female & Male & Female \\
\hline Male & 544 & 36.21 & 40 & 60 & 35 & 53 & 5 & 4 \\
\hline Female & 568 & 47.36 & 41 & 93 & 40 & 77 & 16 & 2 \\
\hline Total & 1112 & 41.91 & 81 & 153 & 75 & 130 & 21 & 6 \\
\hline
\end{tabular}

ried 1 parasite, $47(0.04 \%)$ carried 2 parasites, 1 in each branchial cavity, and 1 specimen carried 3 parasites, 1 in each cavity (branchial and buccal). Moreover, in 2 cases, 2 parasites were found in the same branchial cavity. In the first case a pair of females, and in the second case a male and a female were found.

In all cases, isopods were attached to the anteriorventral portion of the host's gill chambers. Parasites' heads were always directed to the host's ventral side. The parasite's body was bent to the left when it occupied the left branchial cavity, or to the right when it occupied the right branchial cavity. In most cases, the parasite was located between the second and third branchial arches. The parasite was attached either to the vomerine arch or to the internal wall of the branchial operculum with its claw-like pereopods. The affected operculum did not display any obvious effect compared to non-infected ones. A cavity the size of the parasite occurred in the gills and filaments above the site of settlement (Fig. 2). As the parasite grew, there was an increase in the amount of mechanical damage done to the gill. However, there was no obvious bleeding, loss of gill filaments, or discoloration.

The parasites found in the buccal cavities occupied the floor of the lower jaw of the host, and clung firmly to the tongue with their heads oriented towards to the opening of the mouth. In the branchial cavities, the percentage of occurrence of female parasites was greater than males (65.38 and $34.62 \%$, and 63.42 and $36.59 \%$ for females and males in the left and right branchial cavities, respectively). In the buccal cavities, the percentage of males was greater than females $(77.8$ and $22.3 \%$ for male and female parasites, respectively).

The parasite incidence regarding the host's sex was 36.21 and $47.36 \%$ in host males and females, respectively. This difference was found to be statistically significant $\left(\chi^{2}=8.23 ; \mathrm{p}=0.016\right)$. Moreover, no significant difference $\left(\chi^{2}=1.92 ; \mathrm{p}=0.38\right)$ was found between the percentage occurrence of the parasite in relation to the branchial position (53.30 and $46.70 \%$ for the left and right branchial chambers, respectively). The study of percentage prevalence, with regard to size class of the host, shows that prevalence increased with size for the majority of size classes. The prevalence ratio correlated with the length class of the host was 1:2.9 (infested:non infested) for the length class 30 to $40 \mathrm{~mm}$, and increased gradually to reach a ratio of 1:1 (infested:noninfested) for lengths $>50 \mathrm{~mm}$ (Fig. 3).

With the exception of October and November, the monthly prevalence showed no marked variations throughout the year. The lowest percentage 

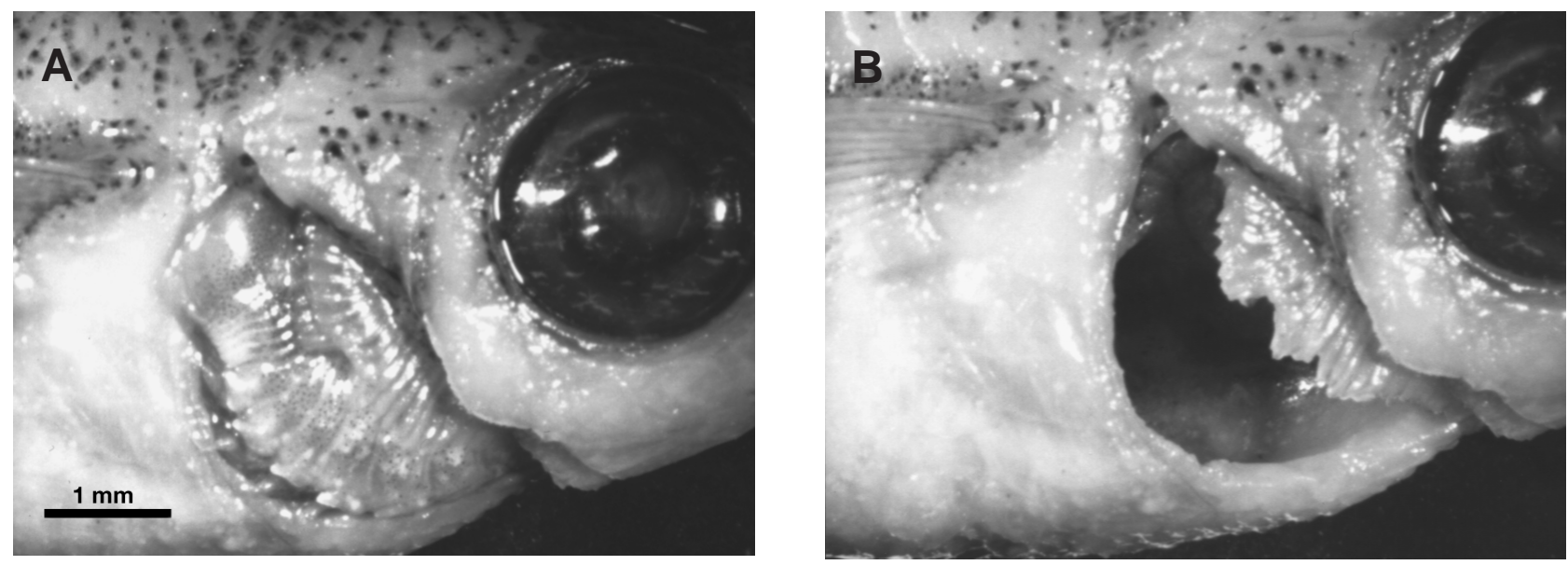

Fig. 2. Atherina boyeri specimen showing parasitic Mothocya epimerica in the branchial cavity. (A) Parasite is attached between the first and second branchial arches of the host. (B) Branchial cavity of the host after the removal of the parasite. The operculum of the sand smelt has been removed

occurred in November $(11.36 \%)$ and the highest in September $(52.50 \%)$, while for all other months the prevalence varied around $40 \%$ (Fig. 4). The overall prevalence was $41.91 \%$.

The smallest Mothocya epimerica found measured $1.7 \mathrm{~mm}$ in length, had a TW of $0.02 \mathrm{mg}$ and was an aegathoid juvenile which had not yet assumed the features of an adult male. The largest male found measured $8.5 \mathrm{~mm}$ with a TW of $26.5 \mathrm{mg}$. The smallest female had a TL of $3.7 \mathrm{~mm}$ and a TW of $1 \mathrm{mg}$, and the largest had a TL of $9.5 \mathrm{~mm}$ and a TW of $94.6 \mathrm{mg}$. The length frequency distribution of parasites shows at least 3 cohorts (Fig. 5). In accordance with Hasselblad's method, the parameters of the isopod length frequency distribution are shown in Table 2. The distributions for male and female parasites are not significantly different from the expected frequencies $\left(\chi^{2}=24.25, \mathrm{df}=17\right.$,

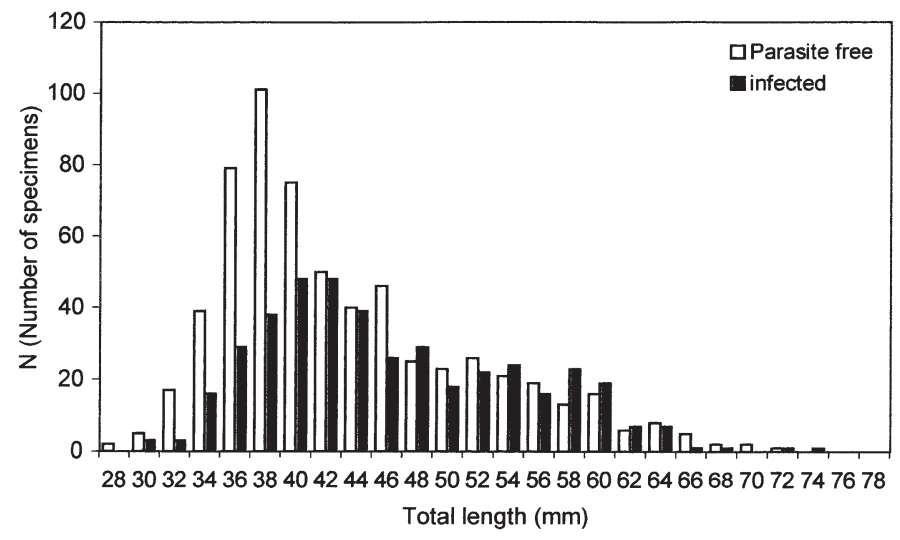

Fig. 3. Size frequency distribution of infested and parasite (Mothocya epimerica)-free specimens of sand smelt Atherina boyeri from Mesolongi and Etolikon Lagoons $\mathrm{p}<0.05 ; \chi^{2}=31.25, \mathrm{df}=21, \mathrm{p}<0.05$ for male and female, respectively).

No significant differences were found between infected and parasite-free hosts regarding length frequency distribution (Kolmogorov-Smirnov test, $\mathrm{p}>0.05$ ).

The relationship between parasite length (PL) and host length (HL) was examined, and a linear regression was found: PL $=1.23+0.091 \mathrm{HL}\left(\mathrm{R}^{2}=0.28, \mathrm{p}<0.001\right)$. Similarly, the relationship between the parasite weight (PW) and host weight (HW) also gave a linear regression: $\mathrm{PW}=0.00056+0.018 \mathrm{HW}\left(\mathrm{R}^{2}=0.37 \mathrm{p}<0.001\right)$.

Parasite mass increased with increasing sand smelt length. The linear regression model (log[parasite mass] $=\mathrm{a}+\mathrm{b} \times \log [$ sand smelt length]) was significant $\left(R^{2}=0.24, p<0.001\right)$, as were both terms of the model $(\mathrm{a}=-7.25, \mathrm{SE}=0.45, \mathrm{p}<0.001 ; \mathrm{b}=3.12, \mathrm{SE}=0.27$, $\mathrm{p}<0.001)$.

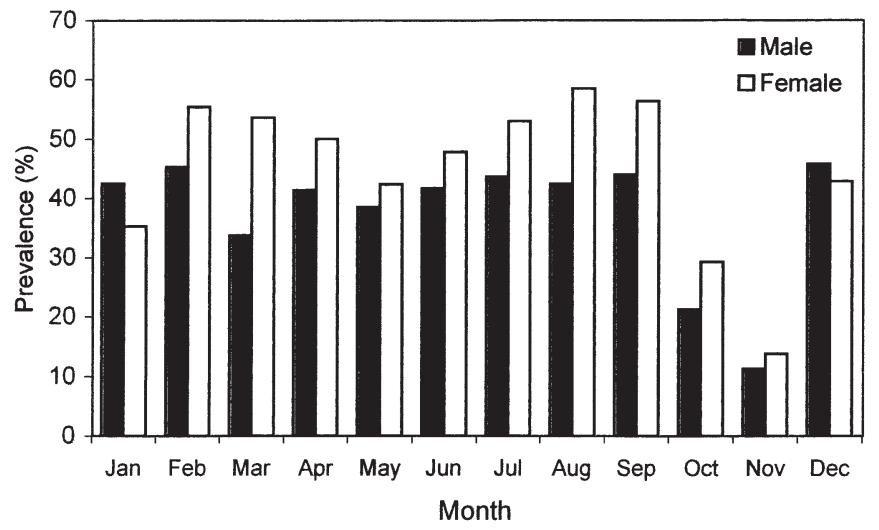

Fig. 4. Monthly variation of parasite Mothocya epimerica prevalence on sand smelt Atherina boyeri from Mesolongi and Etolikon Lagoons 


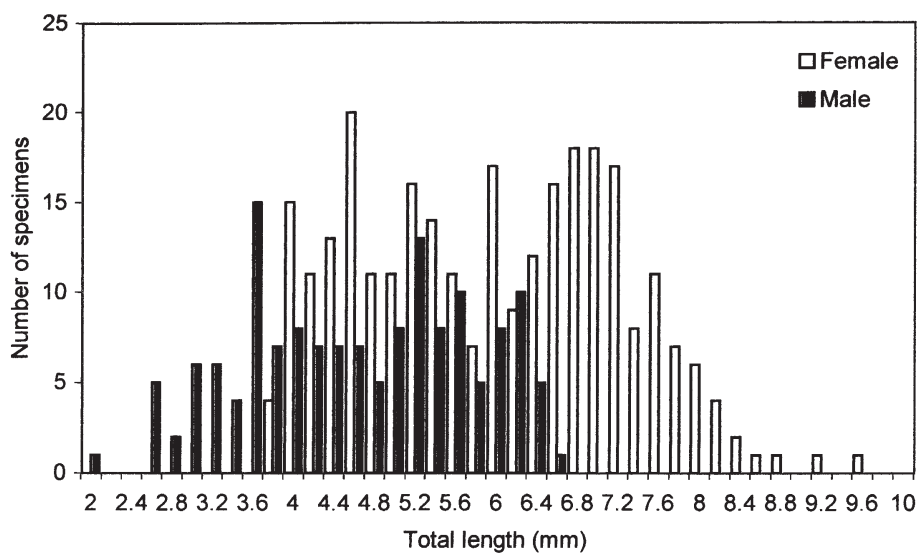

Fig. 5. Size frequency distribution of parasite Mothocya epimerica on sand smelt Atherina boyeri from Mesolongi and Etolikon Lagoons

The relationship between sand smelt mass and sand smelt length was increased more rapidly than the relationship between isopod mass and sand smelt length, although there is no statistically significant difference between the 2 relationships. The allometric coefficient $b$ $\left(\mathrm{NW}=\mathrm{a} \times \mathrm{FL}^{\mathrm{b}}\right)$ for the isopod mass-sand smelt FL relationship ( $b=3.12, \mathrm{SE}=0.27)$ did not significantly differ from that for the sand smelt NW-FL ( $b=3.21, \mathrm{SE}=0.03)$.

The relationship between parasite TL and TW was examined for males, females and both sexes combined (Table 3), and parasite growth was found to be allometrically positive. The slopes of the equations were compared using an ANCOVA, and the slope of the

Table 2. Mothocya epimerica. Analysis of size-frequency distribution using Hasselblad's method (Hasselblad 1966)

\begin{tabular}{|lccccc|}
\hline Sex & Cohort & N & $\begin{array}{c}\text { Mean total } \\
\text { length }(\mathrm{mm})\end{array}$ & SD & $\begin{array}{c}\text { Separation } \\
\text { index }\end{array}$ \\
\hline Male & 1 & 78.90 & 3.57 & 0.67 & \\
& 2 & 46.90 & 5.14 & 0.36 & 3.04 \\
& 3 & 22.20 & 5.99 & 0.18 & 3.13 \\
Female & 1 & 75.01 & 4.06 & 0.34 & \\
& 2 & 28.98 & 5.27 & 0.20 & 3.15 \\
& 3 & 178.02 & 6.73 & 0.89 & 2.68 \\
\hline
\end{tabular}

Table 3. Mothocya epimerica. Relationship between total weight (TW) and length (TL). ${ }^{*}$ Statistically significant difference. $b$ is the exponent in the TW-TL equation

\begin{tabular}{|lccccc|}
\hline Sex & Equation & SE of b & N & $\mathrm{R}^{2}$ & $\mathrm{p}$ \\
\hline Male & $\mathrm{TW}=9.78 \times 10^{-6} \mathrm{TL}^{3.85 *}$ & 0.14 & 178 & 0.82 & $<0.001$ \\
Female & $\mathrm{TW}=6.12 \times 10^{-6} \mathrm{TL}^{4.36 *}$ & 0.09 & 289 & 0.87 & $<0.001$ \\
Total & $\mathrm{TW}=6.5 \times 10^{-6} \mathrm{TL}^{4.26}$ & 0.08 & 467 & 0.85 & $<0.001$ \\
\hline
\end{tabular}

equation for females was higher than that for males $\left(F=10.020, \mathrm{df}^{1}{ }_{464}, \mathrm{p}=0.001\right)$.

The slope of the NW-FL relationship equation for parasite-free specimens was compared to the equation slopes for specimens infected with 1 or 2 parasites. For both sexes the differences among the 3 curves were not statistically significant $\left(F=0.155, \mathrm{df}^{2}{ }_{514}, \mathrm{p}=0.86\right.$ for males, and $F=2.64, \mathrm{df}^{2}{ }_{375}, \mathrm{p}=0.07$ for females). To further corroborate the above result, the length-weight relationship of parasite-free specimens was compared to the corresponding relationship of specimens infected with large gravid female parasites, and no significant differences were found. Moreover, the study of gonadosomatic, hepatosomatic indices and relative condition factor (Fig. 6) revealed no obvious differences between infected and parasite-free specimens.

Investigations of possible infections by Mothocya epimerica of other species (Aphanius fasciatus, Gobius niger, Mugil cephalus, Chelon labrosus, Liza ramada, L. saliens, Gambusia affinis, Blennius ocellaris, Sparus auratus and Dicentrarchus labrax) living in the Mesolongi and Etolikon Lagoons revealed the absence of such infections, despite the fact that specimens of the above species were often caught in the same haul with Atherina boyeri. Furthermore, no specimens of $M$. epimerica were found in sand smelts collected from Trichonis Lake (Fig. 1), which is connected to the lagoon via the coastal area and Acheloos River. A possible explanation for this phenomenon is that the parasite cannot follow its host into inland waters.

\section{DISCUSSION}

The overall prevalence of Mothocya epimerica on Atherina boyeri in the Mesolongi and Etolikon Lagoons $(41.91 \%)$ was higher than that found by Bello et al. (1997) in the Lesina Lagoon $(7.7 \%)$, Trilles (1964b) near the French coast $(12.7 \%)$ and Mariniello \& DiCave (1993) in the Lesina Lagoon (14\%) according to Bello et al. (1997). It appears that the population of $A$. boyeri found in the Mesolongi and Etolikon Lagoons bears the highest degree of infection by $M$. epimerica reported to date.

This unusually high level of infection suggests that the sand smelt is an appropriate host for Mothocya epimerica. The tendency of sand smelt to school, combined with estuarinedependent life traits and one of the highest growth rates (Henderson \& 


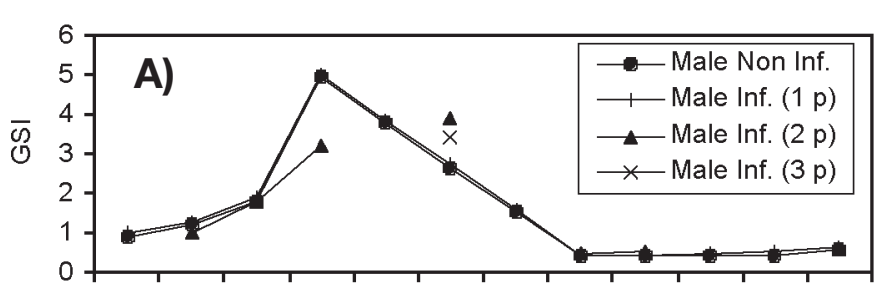

Jan Feb Mar Apr May Jun Jul Aug Sept Oct Nov Dec

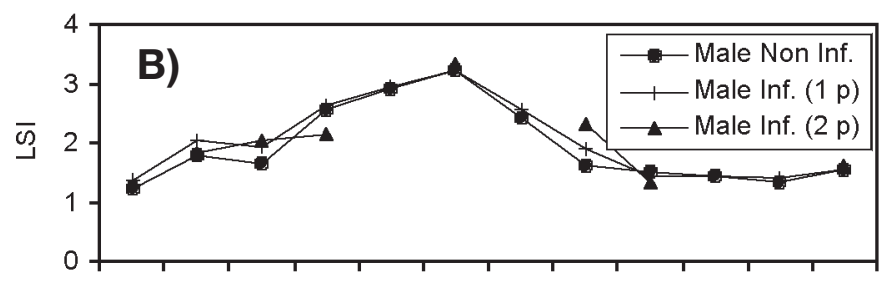

Jan Feb Mar Apr May Jun Jul Aug Sep Oct Nov Dec

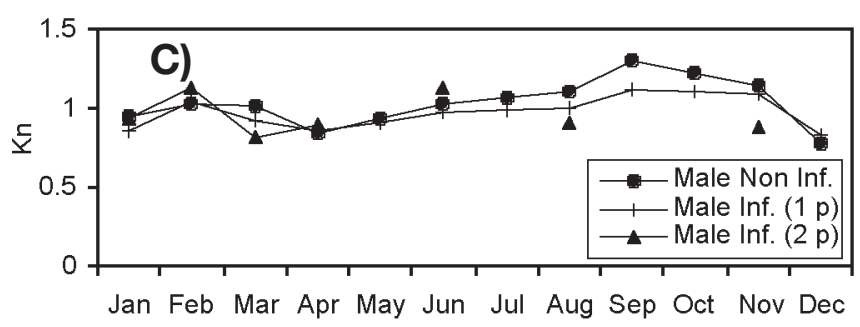

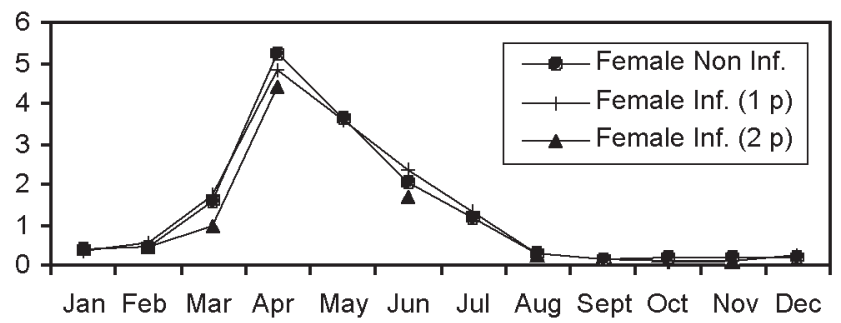
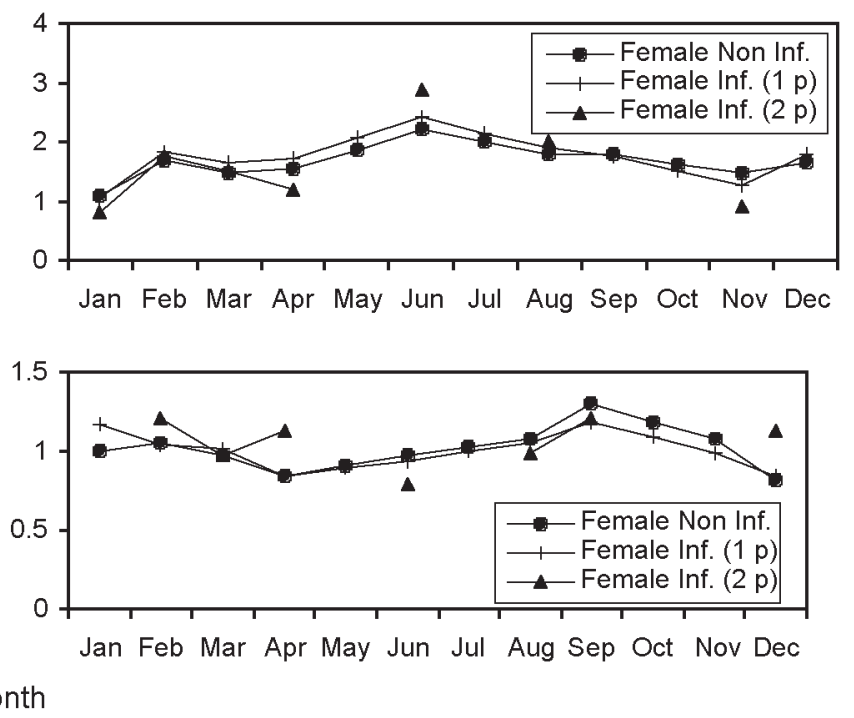

Fig. 6. Monthly variation of the gonadosomatic index (GSI). (A) Hepatosomatic index (LSI), and (B) relative condition factor $(\mathrm{Kn})$ for $(\mathrm{C})$ male and female sand smelt Atherina boyeri from Mesolongi and Etolikon Lagoons. Non Inf = Non-infested specimens; Inf. $(1 \mathrm{p})=$ Infested specimens carrying 1 parasite; Inf. $(2 \mathrm{p})=$ Infested specimens carrying 2 parasites; Inf. $(3 \mathrm{p})=$ Infested specimens carrying 3 parasites

Bamber 1987, Leonardos \& Sinis 2000, Leonardos 2001), may partially explain this host-parasite relationship.

The parasite seems to prefer to infect the left branchial chamber $(53.3 \%)$ than the right $(46.7 \%)$, although this difference was not statistically significant. Similar results were reported by Bello et al. (1997) in Italy, in a study of Mothocya epimerica populations from the Lesina Lagoon $(57.1 \%$ in the left branchial chamber and $42.9 \%$ in the right) and Venice, which showed a statistically significant difference in the parasite's preference $(70.5 \%$ in the left chamber and $29.5 \%$ in the right). The authors attribute this preference to genetic or environmental differences.

The higher frequency of male parasites in the host's buccal cavity (Table 1) suggests that the parasite first subsists in the oral cavity of the host the aegathoid stage, and then enters the branchial cavities or causes the transformation of a pre-existed parasite.

During the sampling procedure, in 2 different instances, 2 specimens of sand smelt demonstrated unusual behavior. They swam sluggishly, separately from their schools and near the surface. In both cases, they carried parasites. In the first case the host was in poor condition and could be caught easily with a small net. It was found that it carried 3 parasites, 1 in the right branchial cavity, 1 on the base of caudal fin and 1 on the base of the dorsal fin. In the other case the host was infested by 2 parasites, the first located in the branchial cavity and the second on the base of the caudal fin. Certainly the presence of parasites on the base of the fins interferes with the swimming ability of the host. In this host-parasite relationship, it seems that the swimming ability of the host is significantly weakened.

During this study, females were significantly more frequently infected than males (47.36 and 36.21\% for females and males respectively) while the sex ratio of the host was 1:1.04 (males:females), not significantly different from 1:1. In agreement with this result, Bello et al. (1997) and Boscolo (1970) found that equal numbers of males and females carry parasites. However, Bello et al. (1977) found that males were infected at a statistically significant higher rate than females, when considering individuals larger than $4 \mathrm{~cm}$ SL.

The peaks in the monthly distribution of prevalence (Fig. 4) correspond to the recruitment of the newborn 

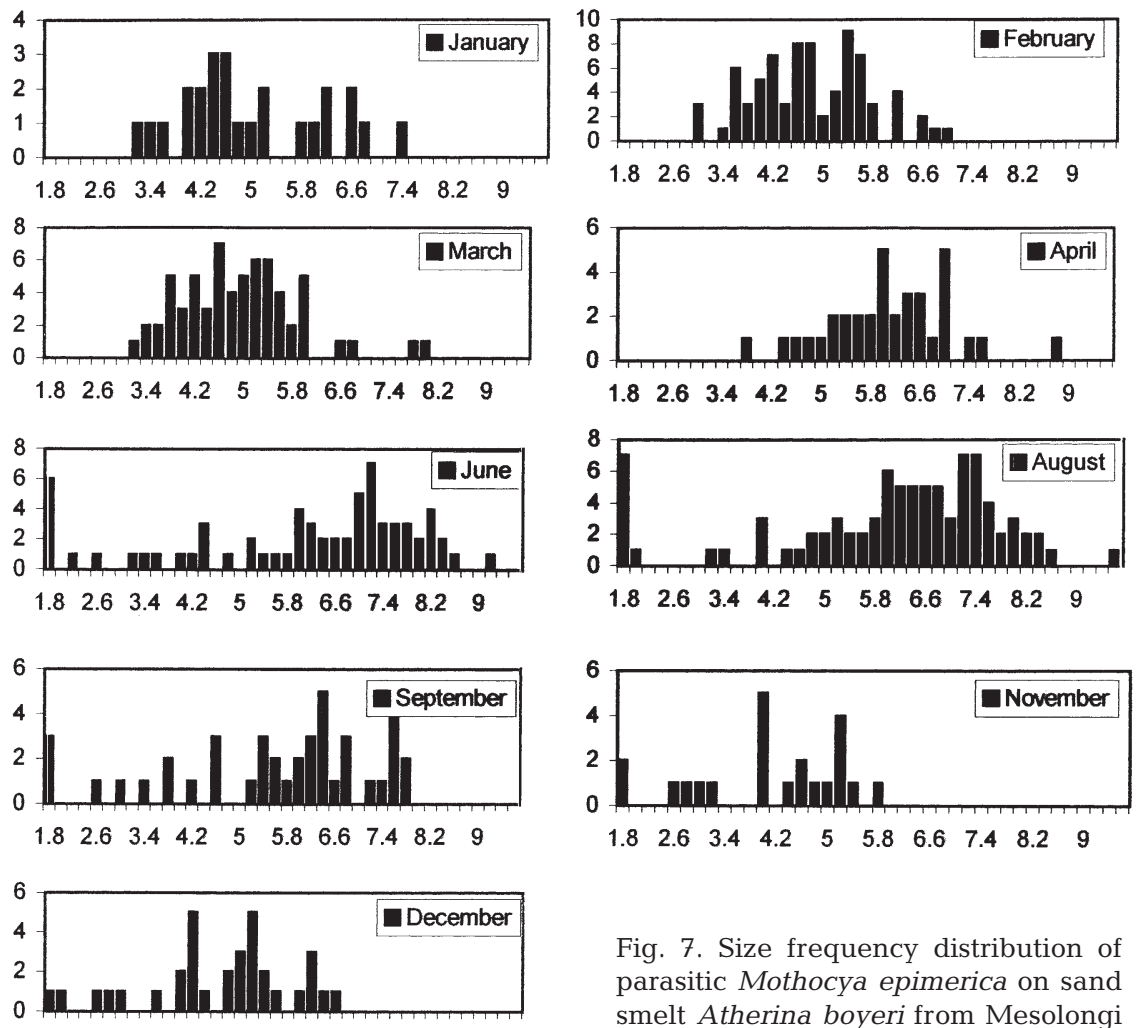

$\begin{array}{llllllllll}1.8 & 2.6 & 3.4 & 4.2 & 5 & 5.8 & 6.6 & 7.4 & 8.2 & 9\end{array}$

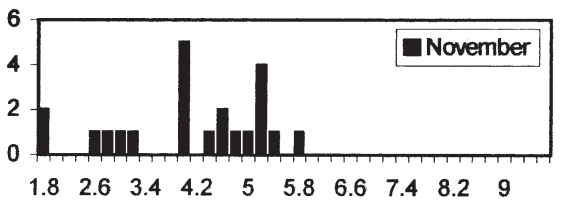

Fig. 7. Size frequency distribution of parasitic Mothocya epimerica on sand smelt Atherina boyeri from Mesolongi and Etolikon Lagoons

the area on which the female parasite rests its abdomen (inner edges of the gill and branchial arch) is most likely a consequence of the energetic beating of her pleopods for ventilation. This activity appeared to be particularly intensive in females removed from their hosts. However, none of the infected fish displayed any obvious sign of respiratory distress or depressed growth when compared with non-infected fish.

Since the parasite has a relatively large size compared to the host's size, it would be expected that such infections would impair the growth of the host and cause serious damage to its gills. Furthermore, it would be expected that this damage would negatively affect sand smelt's growth and survival.

The comparison of the slopes of the FL-NW relationship equations between parasite-free and infected specimens showed that there were no statistically significant differences. In some cases, it was detected that the body condition of infected specimens was even superior to that of parasite-

parasites. This mode shows that the recruitment lasts at least from June to December. During the summer months, the percentage prevalence increased, indicating that the parasite takes advantage of favorable conditions (temperature, productivity, presence of hosts) for reproduction. The decrease in prevalence during November and December may be attributed to natural mortality.

The size frequency distribution of male and female Mothocya epimerica shows the coexistence of 3 size classes for each sex. The first size class of males (Table 2) consists of young specimens that cannot develop into females, while the other two are of adult males which have not yet had the possibility to change sex, maybe due to the absence of a second parasite. Therefore, the sex inversion of $M$. epimerica occurs within the range of TL 3.7 to $6.7 \mathrm{~mm}$, and can affect members of 2 (among 3) size classes (Fig. 5).

Adult Mothocya epimerica females, especially when their marsupia are swollen with eggs or larvae, must significantly reduce the water flow through the sand smelt's branchial cavity. Because of the relative size of host and parasite (mean TL of parasite: $5.39 \mathrm{~mm}$, mean FL of the host: $46.12 \mathrm{~mm}$ ), breathing and, subsequently, the host's growth rate are reduced. Colorni et al. (1997) reported that the tissue damage observed in free specimens. Moreover, no statistically significant differences were found even when parasite-free specimens were compared with specimens infected with large, gravid female parasites.

No obvious differences were found between infected and parasite-free sand smelts in relation to gonadosomatic index, hepatosomatic index and relative condition factor.

The negative impact of parasites on host's growth and survival has been demonstrated for several parasite-fish host systems, both in aquaculture and in natural populations (Sindermann 1987). However, hostparasite relationships are in general very complex and difficult to clarify. With the exception of cases of mass mortalities caused by outbreaks of parasites, assessment of the effects of parasite infection in natural fish populations is particularly difficult because of the presence of predators or scavengers which rapidly remove moribund or dead fish.

In this report, a host-parasite relationship was studied and it appears that parasitosis has no negative effects for the host. Similar studies (Weinstein \& Heck 1977, Marks et al. 1996) have even shown a positive significant hostparasite relationship. The linear correlation between the host and parasite size shows 1 of 2 strategies. In the first strategy, infection occurs early in the life of the fish and 
then the parasite grows with the host. In the second strategy, the isopod grows rapidly after the infection to a maximum size and, given the restricted environment of the host's branchial cavity, inhibits further growth. The low value of the correlation coefficient between parasite size and host size $\left(R^{2}=0.28\right.$ or $\left.=0.37\right)$ indicates a high degree of variability that may reflect differences in host size at the time of infection. This suggests that the second strategy is more probable.

According to Combes (1977), parasites improve their fitness as a result of the selection of traits, which determine their relationship with their hosts. Some parasites increase their fitness by increasing their pathogenic effect, in order to obtain a higher fecundity or a higher probability of transmission. Others parasites increase their fitness by decreasing their pathogenicity, if they can benefit from longer survival within the host. In this case, the parasite lives on its host without killing it. The survival of the host is important, and the parasite consumes the host's fluids in a manner that does not cause serious harm to the host (Nikolsky 1963). It seems that Mothocya epimerica tends to follow the second strategy.

Several aspects of isopods' life history support the concept that cymothoids may parasitize in a manner that does not constitute a serious threat to the host's life. In the case of parasitosis with the survival of the host, the infection may affect all the members (Nikolsky 1963), or a large portion of the population (such as $41.72 \%$ in this case).

This host-parasite relationship has all the characteristics of an evolutionary process of an adaptive strategy, in which the parasite permits the host to maintain its feeding ability, while it grows to sexual maturity. This could be explained by the assumption that the host's survival is useful to the parasite. This assumption is subtended by the observation that the parasite is usually represented by a single individual in each host, which could be interpreted as having an adaptive value in relation to host health.

\section{LITERATURE CITED}

Bamber R, Henderson PA (1988) Pre-adaptive plasticity in atherinids and the estuarine seat of the teleost evolution. J Fish Biol 33:17-23

Bello G, Vaglio A, Piscitelli G (1997) The reproductive cycle of Mothocya epimerica (Isopoda: Cymothoidae) a parasite of the sand smelt, Atherina boyeri (Osteichthyes: Atherinidae) in the Lesina Lagoon, Italy. J Nat Hist 31: 1055-1066

Boscolo L (1970) Observazoni sulla biologia e sulla pesca dell, Atherina boyeri Risso, 1810 (Osteichthyes Atherinidae) vivente nelle acque dell' alto Adriatico. Boll Pesca Piscic Idrobiol 25:61-79

Bruce NL (1986) Revision of the isopod crustacean genus Mothocya Costa, in Hope, 1851 (Cymothoidae: Flabellif- era), parasitic on marine fishes. J Nat Hist 20:1089-1192

Brusca RC (1978) Studies on the cymothoid fish symbiosis of the eastern Pacific (Crustacea: Isopoda: Cymothoidae). II. Systematics and biology of Lironeca vulgaris Stimpson 1857. Occas Pap Allan Hancock Found New Ser 2: 1-19

Brusca RC (1981) A monograph on the Isopoda: Cymothoidae (Crustacea) of the eastern Pacific. Zool J Linn Soc 73: 117-199

Colorni A, Trilles JP, Golani D (1997) Livoneca sp. (Flabellifera: Cymothoidae), an isopod parasite in the oral and branchial cavities of the Red Sea silverside Atherinomorus lacunosus (Perciformes, Atherinidae). Dis Aquat Org 31: $65-71$

Combes C (1977) Fitness of parasites: pathology and selection. Int J Parasitol 27:1-10

Creech S (1992) A study of the population biology of Atherina boyeri Risso, 1810 in Aberthaw Lagoon, on the Bristol Channel, in South Wales. J Fish Biol 41:277-286

Fernandez-Delgado C, Hernando JA, Herrera M, Bellido M (1988) Life history patterns of the sand smelt Atherina boyeri Risso, 1810 in the estuary of the Guadalquivir River, Spain. Estuar Coast Shelf Sci 27:697-706

Gayanilo FC Jr, Pauly D (1997) The FAO-ICLARM stock assessment tools (FiSAT) reference manual. FAO Computerized Information Series (Fisheries), No 8, Rome

Gon O, Ben-Tuvia A (1983) The biology of Boyer's sandsmelt, Atherina boyeri Risso, in the Bardawil Lagoon on the Mediterranean coast of Sinai. J Fish Biol 22:537-547

Grabda J (1991) Marine fish parasitology, an outline. Polish Scientific Publishers, Warsaw

Hasselblad V (1966) Estimation of parameters for a mixture of normal distributions. Technometrics 8:431-444

Henderson PA, Bamber R (1986) Sand smelt in the fleet. Porcupine Newslett 3(6):149-151

Henderson PA, Bamber R (1987) On the reproductive biology of the sand smelt Atherina boyeri Risso (Pisces: Atherinidae) and its evolutionary potential. Biol J Linn Soc 32:395-415

Kabata Z (1984) Diseases caused by metazoan: crustacean. In: Kinne O (ed) Disease of marine animals, Vol 4, Part 1. Introduction, Pisces. Biologische Anstalt Helgoland, Hamburg, p 321-347

Kiener A, Spillman CJ (1969) Contribution à l'étude systematique et ecologique des atherines des côtes françaises. Mem Mus Nat Hist Nat Nouv Ser A 40:33-74

Kohler A (1976) Observations biologiques et biometriques sur Atherina boyeri Risso dans l'étang du Prevost à Palavas (Herault). Vie Milieu 26(1-A):157-174

Landau M, Danko MJ, Slocum C (1995) The effect of the parasitic cymothoid isopod (Lironeca ovalis) (Say) on growth of young-of-the-year bluefish (Pomatomus saltatrix). Crustaceana 68:397-400

Leonardos I (2001) Ecology and exploitation pattern of a landlocked population of sand smelt, Atherina boyeri (Risso, 1810), in Trichonis Lake (western Greece). J Appl Ichthyol 17:262-266

Leonardos I, Sinis A (2000) Age, growth and mortality of Atherina boyeri Risso, 1810 (Pisces: Atherinidae) in the Mesolongi and Etolikon Lagoons (W. Greece). Fish Res 45: 81-91

Mariniello L, DiCave D (1993) Isopodi parassiti di specie ittiche di interesse commerciale presenti nel lago di Lesina. Biol Mar 1:233-238

Marks R, Juanes F, Hare J, Conover D (1996) Occurrence and effect of the parasitic isopod Lironeca ovalis (Isopoda: Cymothoidae), on young-of-the-year bluefish, Pomatomus 
saltatrix (Pisces: Pomatomidae). Can J Fish Aquat Sci 53: 2052-2057

Moller H, Anders K (1986) Diseases and parasites of marine fishes. Moller, Kiel

Nikolsky GV (1963) The ecology of fishes. Academic Press, London

Palmer C, Culley M (1983) Aspects of the biology of the sandsmelt Atherina boyeri Risso, 1810 (Teleostei: Atherinidae) at Oldbury-upon-Severn, Gloucestershine, England. Estuar Coast Shelf Sci 16:163-172

Palmer CJ, Culley BM, Claridge NP (1979) A further occurrence of Atherina boyeri Risso 1810 in North-Eastern Atlantic waters. Environ Biol Fish 4:71-75

Radujkovic B, Romestand B, Trilles JP (1984) Les parasites de la faune Yougoslave. I. Cymothoidae parasites de poissons de la region de l'Adriatique Meridionale. Acta Adriatica 25(1/2):161-181

Romestand B, Trilles JP (1979) Influence of the cymothoid isopods Meinertia oestroides, Meinertia parallela and Anilocra physodes (Crustacea; fish parasites) on the growth of fish hosts Boops boops and Pagellus erythrinus (Sparidae). Z Parasitenkd 59:195-202

Sindermann CJ (1987) Effects of parasites on fish populations: practical considerations. Int J Parasitol 17:371-382

Editorial responsibility: Wolfgang Korting,

Hannover, Germany
Sindermann CJ (1990) Principal diseases of marine fish and shellfish, Vol I. Academic Press, London

Trilles JP (1964a) Specificité parasitaire chez les isopodes Cymothoidae mediterranneens (Note préliminaire). Vie Milieu 15:105-116

Trilles JP (1964b) Note preliminaire sur quelques aspects de la reproduction chez les isopodes Cymothoidae Mediterrannéens. Arch Zool Exp Gen 104:127-134

Trilles JP (1968) Recherches sur les isopods cymothoidae des côtes françaises, Vol I: Bionomie et parasitisme. PhD thesis, Université de Montpellier

Trilles JP (1991) Present researches and perspectives on Isopoda (Cymothoidae and Gnathiidae) parasites of fishes (systematics, Faunistics, Ecology, Biology and Physiology). Wiad Parazytol 37:141-143

Trilles JP (1994) Les Cymothoidae (Crustacea, Isopoda) du monde (prodrome pour une faune). Stud Mar 21/22(1-2): $5-288$

Weinstein MP, Heck KL Jr (1977) Biology and host-parasite relationships of Cymothoa excisa (Isopoda, Cymothoidae) with three species of snappers (Lutjanidae) on the Caribbean coast of Panama. Fish Bull 75:875-877

Zar JH (1984) Biostatistical analysis, 2nd edn. Prentice Hall, Englewood Cliffs, NJ

Submitted: June 28, 2002; Accepted: January 30, 2003

Proofs received from author(s): March 31, 2003 